\title{
The Design of Intelligent Drip Irrigation Network Control System
}

\author{
${ }^{1}$ Mr. S.G. Galande, \\ Ph.D. Scholar, RTMNU, Associte Prof, PREC,Loni, \\ Email : sggalande@gmail.com
}

${ }^{2}$ Dr. G.H. Agrawal,

Professor, KDK Engineering College, Nagpur

Email :ghagrawal66@yahoo.com

${ }^{3}$ Mr. N.B Waditke,

PREC, Loni

Email.: nanasahebwaditake1@gmail.com

\begin{abstract}
In Conventional drip irrigation system more man power is require to operate the system but in the developed system which helpful to reduce the man power and provide water time to time for the plant automatically. In this system used various type of sensor such as Temperature, Humidity, pH, Moisture 1, Moisture 2, light intensity, PH_EC sensor. The system measures nitrogen $(\mathrm{N})$, potassium $(\mathrm{K})$, phosphorus $(\mathrm{P})$ using PH_EC sensor in the soil according to soil condition the appropriate fertilizers are mixed in the soil for increasing the crop productivity. Also the System measure moisture, temperature, humidity and light intensity, $\mathrm{pH}$ according to that appropriate action will be taken. All the sensors are interface to the ARM 7. The processer will process the data display it and as well as control the solenoid valve when moisture is 20 percent then valve will ON and moisture is 80 percent then valve will OFF. The main advantages of this system are to reduce the man power, electricity, save water and improve the production. With the help of this system the farmer can handle the large field very easily.
\end{abstract}

Keywords-PH EC Sensor for the measurement of N, P, K sensor.

\section{INTRODUCTION}

In India the economy is depend on agriculture field. In India population is increasing the food requirement go on increasing manner to meet the requirement the production is very important. To improve the production manage and measure of agricultural parameter is important. Now a days water resources are also reduce so to provide a required amount of water to the plant is a need of agricultural field if amount of fertilizer is more than it affect the crop. The aim of this system is one of the best water-saving irrigation technology. It is also helpful to manage and measure agricultural parameters with drip irrigation system. This system measure the parameters like temperature ,pH, Humidity, light intensity ,moisture and main nutrient of the soil .The drip design has been partitioned into sensor, control unit, valves and planning subsystems.

This System deals with the design, optimization and development of a practical solution for application to the agricultural monitoring and control. The proposed system utilizes PH EC sensor for measurement of N,P,K.. After the proper measurement of N,P,K content from soil it will become simple to judge about the fertilizer combinations. With the help of this technology we can increase the production and reduce the man power. The production is depend on the various parameter such as fertilizer and providing water time to time. The fertilizer and the water is most important. The parameter is changing due to change in environment and other conditions. But our aim is to sense the parameter and then provide the water and fertilizer.

\section{THE GOALS OF THE SYSTEM DESIGN}

Modular Design:- In this developed system the various parameter are sense to control the drip irrigation system and measure the main nutrient of soil and provide the nutrient as per requirement. For this system there is various sensor, processer and Display unit. 
International Journal of Engineering Research and General Science Volume 3, Issue 3, May-June, 2015

ISSN 2091-2730

Low-cost and Stable network:-The design system is low-cost and wired communication network to achieve intelligent management without the construction of large communication devices

\section{SYSTEM ARCHITECTURE AND SOFTWARE DESIGN:-}

\section{A.Sensor:-}

This system measure different parameter of environment and analysis the data for this different sensor are required to measure various parameter are as follows.

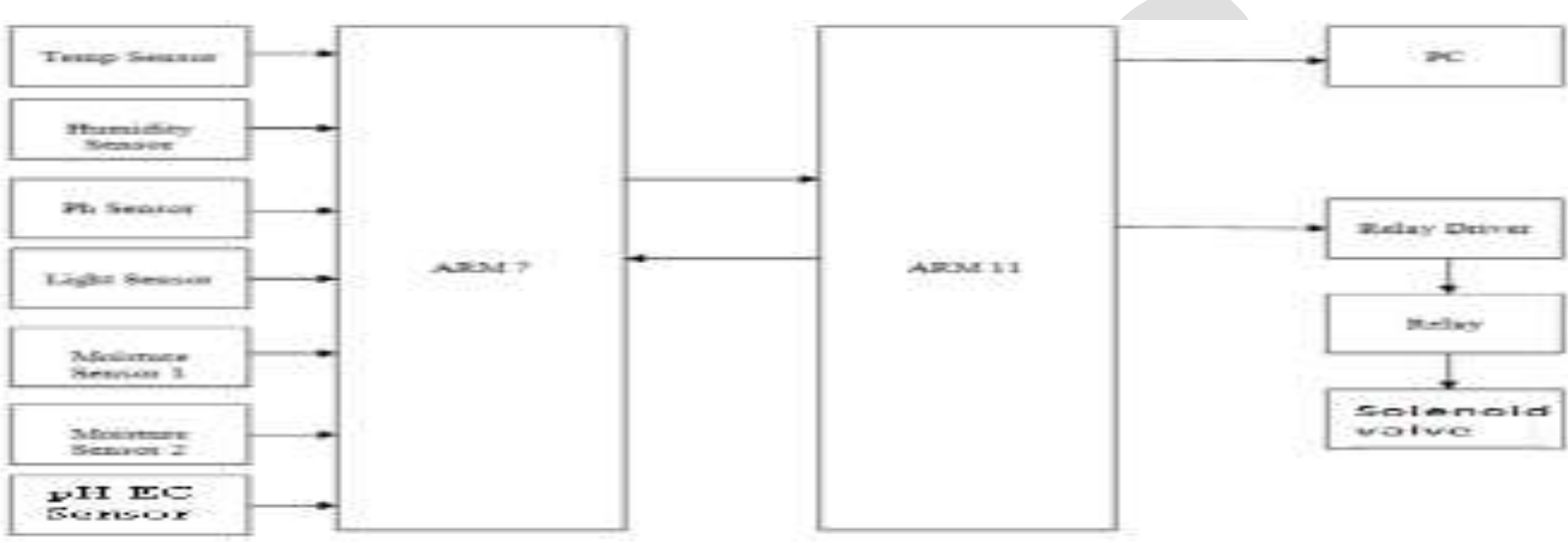

\section{1) Humidity Measurement:-}

Humidity is most important parameter of agriculture field. As there is many types of humidity sensors. In this system SY HS220 humidity sensor is used. The output of this sensor is in voltage which is proportional to relative humidity. At $20 \%$ relative humidity, the output is $680 \mathrm{mV}$, while at $90 \%$ relative humidity; the output is $2980 \mathrm{mV}$, i.e. $2.97 \mathrm{~V}$. The output of the Humidity sensor is connected to the ARM 7 processor at pin no P0.25.

\section{2) pH Measurement:-}

To measure $\mathrm{pH}, \mathrm{pH}$ electrods are used. In this system FC-28-c sensor is used to measure the $\mathrm{pH}$. It operates in 4-20 $\mathrm{mV}$. So pre amplifier is required with high input impedance. The ADC is used to convert analog to digital o/p. Power requirements $0-5 \mathrm{VDC}$.

\section{3) Moisture Measurement:-}

To measure moisture, simple two iron rod (Soil moisture sensor) is used.It has moisture Range 0-100 Centibar,Output 4-20 mA ,Power Requirements 0to5 VDC,Current Consumption $20 \mathrm{~mA}$ max.In this system design two moisture sensor for controlling two solenoid valve. If moisture is $20 \%$ then solenoid valve will be $\mathrm{ON}$ and if moisture is $80 \%$ then solenoid valve will be $\mathrm{OFF}$.

4) LM35 Temperature sensor for soil:- To measure temperature LM35 Temperature sensor is used. It having linear $+10 \mathrm{mV} /{ }^{\circ} \mathrm{C}$ Scale Factor ,Calibrated Directly in ${ }^{\circ}$ Celsius (Centigrade) , $0.5^{\circ} \mathrm{C}$ Ensured Accuracy (at $+25^{\circ} \mathrm{C}$ ) , Rated for Full $-55^{\circ} \mathrm{C}$ to $+150^{\circ} \mathrm{C}$ Range, Operating voltage range is from 4 to $25 \mathrm{~V}$.

5) Main nutrient sensor:- To measures N,P,K, PH-EC sensor is used. This sensor gives different $\mathrm{pH}$ values for different nutrients. The $\mathrm{Ph}$ value $\mathrm{N}$ and $\mathrm{P}$ is in between 6-7, and $\mathrm{K}$ has 7-8.

\section{6) Light Intensity Measurement:-}


International Journal of Engineering Research and General Science Volume 3, Issue 3, May-June, 2015

ISSN 2091-2730

For light intensity measurement, The LDR sensor is used. LDR is Light Dependent Resistor. As light intensity increases, the resistance decreases, and resistance increase light intensity decreases. In this system designed a voltage divider network using LDR and a resistance. As the intensity changes, the voltage drop across the LDR also changes, and hence potentials proportional to the light intensity.

\section{B. Control and measure unit:-}

The output of temperature sensor is given to pin no of P0.4 to ARM 7 and the processer will process and display the data on Display. The output of humidity sensor is given to pin no of P 0.25 to ARM 7 and the processer will process and display the data on Display. The output of $\mathrm{pH}$ sensor is given to pin no of P 0.12 to ARM 7 and the processer will process and display the data on Display. The output of Moisture 1 and Moisture 2 sensor is given to pin no of P 0.28 and P0.29 to ARM 7 and the processer will process and display the data on Display. The output of Light intensity sensor is given to pin no of P 0.10 to ARM 7 and the processer will process and display the data on Display. The output of PH EC sensor for NPK is given to pin no of P 0.22,P0.15,P0.13 to ARM 7 and the processer will process and display the data on Display.

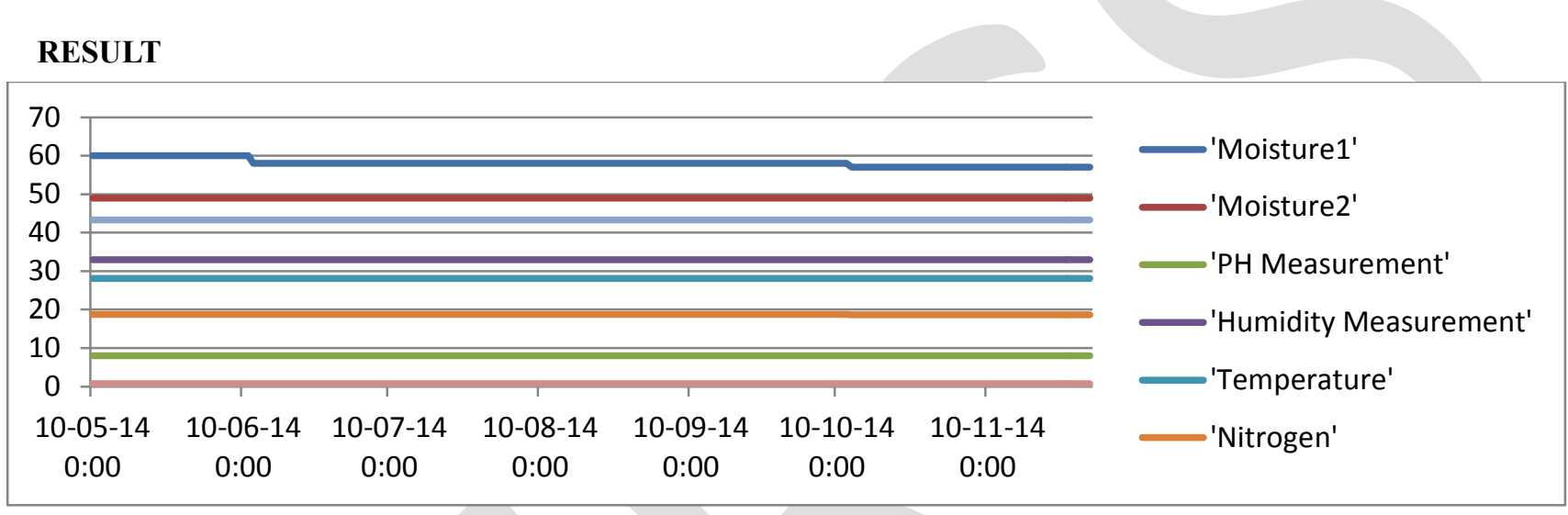

Figure represent the Date verses all the parameters. The Moisture sensor 1 place in plot 1 and Moisture sensor 2 place in plot 2 . pH sensor,PH_EC sensor are placed in the soil. All other sensors are sense the environmental parameters. The date wise data is recorded and it is represented in the above graph. The graph is used for analysis purpose.

The advantage of this system is handle the large agriculture field with less man power. This system also required less amount water, electricity.

\section{CONCLUSION}

This system is useful to increase the production and reduce the man power and save the electricity. This System deals with the design, optimization and development of a practical solution for application to the agricultural monitoring and control. The system utilizes sensor for Micro parameter measurement (N,P,K),temperature level detection, Motion detection , Humidity , Soil moisture ,Soil Ph For management of Agricultural environment. It included The design of intelligent drip irrigation network control system After the proper measurement of $\mathrm{N}, \mathrm{P}, \mathrm{K}$ content from soil it will become simple to judge about the fertilizer combinations.

\section{REFERENCES:}

1] $\mathrm{Xu}$ Wei, Huang Houkuan, and Wang Yingjie, “An Integrated Spatio-Temporal Forecasting Approach Based on Data Fusion and MethodFusion,” Journal of Computer Research and Development, vol. 42,pp.1255-1260, July 2005. 
International Journal of Engineering Research and General Science Volume 3, Issue 3, May-June, 2015

ISSN 2091-2730

[2] Zheng Yao and Li Jiangquan, "Empoldering Monitoring System of Mulch Trickle Irrigation for Cotton Based on Industrially Controlled Configuration Software,’The Reseasch of Agricultural Mechanization, pp. 073-03, June 2009.

[3] Yang Ting and Wang Xiaochan, "Design on Automatic Drip Irrigation System Based on ZigBee Wireless Sensor Network," Computer Measurement \& Control, vol. 18, pp.1332-03, June 2010.

[4] Sun Shiwei, Zhang Tiebi, Wang Haisong, Wang Fengrui, and He Hong, "Realization of Fuzzy Control Algorithm in Drip Irrigation System,” The Reseasch of Agricultural Mechanization, pp. 063-04, June 2010.

[5] Hat hoot H M, Abo-Ghobar H M, Al-Amoud A I, et al."Analysis and design of sprinkler irrigation laterals,” ASCE Jouranal of Irrigation and Drainage Engineering, vol. 120, pp.534-549, March 1994.

[6] Bralts V F, Segerlind L J. "Finite element analysis of drip irrigation submain units[J]," Transactions of the ASAE, vol. 28, pp.809-814, March 1985.

[7] Dnyaneshwar Wavhal and Manish giri "Automated intelligent wireless drip irrigation using linear programming” International Journal of Advanced Research in Computer Engineering \& Technology (IJARCET) Volume 2, Issue 1, January 2013, ISSN: 2278 1323, pp. $1-5$

[8] Dnyaneshwar Wavhal and Manish Giri “Automated Drip Irrigation Improvements Using Wireless Application”, International Journal of Advance Research, IJOAR .org, Volume 1, Issue 3, March 2013, Online: ISSN 2320-9194, pp.65-73

[9] Dnyaneshwar Wavhal, Manish Giri and Sneha Ghumatkar "Decision Support Support System for Drip Irrigation ", International Journal of Emerging Technology and Advanced Engineering, Website: www.ijetae.com (ISSN 2250-2459, ISO 9001:2008 Certified Journal, Volume 4, Issue 4, April 2014, pp.463-470

[10] Mahir Dursun and Semih Ozden "A wireless application of drip irrigation automation supported by soil moisture sesors",Scientific Research and Essays Vol. 6(7), pp. 1573-1582, 4 April, 2011 .Available on- line at http://www.academicjournals.org/SRE ISSN 1992-2248 1'2011 Academic Journals.

[11] Awati J.S., and Patil V.S. ETC department, RIT, Sakharale, Sangli, MS, India.SETI, Panhala, Kolha pur, MS, India. "Automatic Irrigation Control by using wireless sensor networks", Journal of Exclusive Management Science - June 2012-Vol 1 Issue 6 - ISSN 2277 - 5684.

[12] Shiv Sutar, Swapnita-Jayesh, Komal-Priyanka MIT- COE, Pune, Mahrashtra. "Irrigation and Fertilizer control for Precision Agriculture using WSN: Energy Efficient Approach", International Journal of Advances in Computing and Information Researches, ISSN: 2277-4068, Volume 1 No.1, January 2012 